\title{
EFEKTIVITAS PENYIDIKAN TINDAK PIDANA PENAMBANGAN EMAS TANPA IZIN DI KABUPATEN SOLOK SELATAN (Studi pada Direktorat Reserse Kriminal Khusus Kepolisian Daerah Sumatera Barat)
}

\author{
Darmadi Prapto Pamungkas \\ Program Magister Ilmu Hukum, Universitas Ekasakti \\ Email : pamungkasdp@gmail.com
}

\begin{abstract}
Indonesia is the rich country of mine, such as gold, silver, petroleum, mine, etc. Management of mine should be done by government or private. Every mining company obligated to get license as regulated in the Regulation Number 4 Year 2009 about Mineral Mining Juncto the Government Regulation Number 23 Year 2010 about the Implementation of Mineral Mining. In fact, not all companies have license. There are so many companies operate illegal. One of them is gold mining without license (PETI). The specification of the research is descriptive analytic. The methods used are normative as primary approach and juridical empiric method as secondary approach. The sources of data are secondary and primary. The techniques of collecting data uses field study by interviewing for the primary data and library study for the secondary data. Then, the data analyzed qualitatively in descriptive qualitative form. From the research results obtained several conclusions: First, the effective of investigation gold mining without license by Directory of Reserve Special Criminal of West Sumatera Police based on the data got can be seen clearly effective because from 3 (three) cases all has been investigation and submitted to Court. Second, the obstacles faced by Directory of Reserve Special Criminal of West Sumatera Police in executing of gold mining without license (PETI) in South Solok Regency consist of: (a) no synergy in supporting the law enforcement together between instances and other because the agents of gold mining without license (PETI) are backed up by law enforcer, government until traditional viewers; and (b) limited tool such as no double garden cars or boat to reach field and no communication satellite which can be operated in the unreached location by phone signal.
\end{abstract}

Keywords: Efektivitas, Tindak Pidana, Penambangan Emas Tanpa Izin.

\section{PENDAHULUAN}

Indonesia merupakan negara yang kaya akan bahan galian (tambang), yang meliputi emas, perak, tembaga, minyak dan gas bumi, batu bara dan lain-lain. Bahan galian tersebut dikuasai oleh negara, hak penguasaaan negara berisi wewenang untuk mengatur, mengurus dan mengawasi pengelolaan atau pengusahaan bahan galian, serta berisi kewajiban untuk mempergunakan nya sebesar-besarnya kemakmuran rakyat, penguasaan oleh negara dilaksanakan oleh pemerintah. ${ }^{1}$

Pengelolaan barang tambang dapat dilakukan oleh pihak pemerintah atau pihak swasta. Pihak swasta terdiri atas perusahaanperusahaan yang beroperasi untuk melakukan kegiatan penambangan. Setiap perusahaan

${ }^{1}$ Danny Z. Herman, Pertambangan Tanpa Izin (PETI) dan Kemungkinan Alih Status Menjadi Pertambangan Skala Kecil, Kelompok Kerja Konservasi - Pusat Sumber Daya Geologi, Jakarta, 2009, hlm. 54 
pertambangan memiliki kewajiban untuk memperoleh izin usaha pertambangan untuk dapat melaksanakan izin usahanya. Izin tersebut dikeluarkan oleh Pemerintah sesuai dengan wilayah yang ditentukan dalam izin tersebut. Dalam hal ini setiap perusahaan hanya dapat mengantongi satu Izin Usaha Pertambangan (IUP) saja. ${ }^{2}$

Kenyataan menunjukkan bahwa tidak semua perusahaan pertambangan memiliki izin. Ada banyak perusahaan yang beroperasi secara ilegal (tidak resmi) yang sering juga dikenal dengan nama Pertambangan Emas Tanpa Izin (PETI). Kegiatan usaha PETI secara umum menunjang pembangunan ekonomi dan sosial masyarakat, namun di balik itu kebanyakan operasi penambangan menimbulkan kerusakan lingkungan atau tata ruang penggunaan lahan serta mengabaikan perlindungan terhadap kesehatan dan

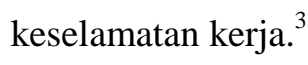

Perkara pidana penambangan tanpa izin merupakan tindak pidana yang sangat berbahaya yang mengancam keamanan dan integrasi NKRI serta menimbulkan kerugian baik dari aspek ekonomi, sosial, dan politis.

Mengantisipasi kemungkinan peningkatan dampak negatif dari keberadaan PETI, pemerintah dan DPR membuat UU No. 11 Tahun 1967 tentang Ketentuan-Ketentuan Pokok Pertambangan yang berkaitan dengan

\footnotetext{
${ }^{2}$ Ibid, hlm. 55

${ }^{3}$ Kompas, Pemberdayaan Pertambangan Skala Kecil Belum Optimal, Edisi 09 Desember 2011, hlm. 27
}

upaya penghentian semua usaha pertambangan tersebut, dengan pengecualian dapat melanjutkan usahanya apabila berstatus pertambangan rakyat untuk bahan galian intan dan tambang tradisional untuk bahan galian emas.

Pada tahun 1998 terjadi pergantian pemerintahan yang membawa Indonesia ke nuansa demokratisasi. Hal ini berpengaruh kepada upaya penanggulangan PETI melalui penentuan kebijakan yang berkaitan dengan pertambangan skala kecil yang berorientasi kepada ekonomi kerakyatan. Kemudian Pemerintah berupaya untuk merealisasikannya dengan membuat peraturan tentang pertambangan resmi berskala kecil melalui penetapan Keputusan Bersama Menteri Pertambangan dan Energi, Menteri Dalam Negeri dan Menteri Pengusaha Kecil dan Menengah Nomor 2002.K/20/MPE/1998 Nomor 151A Tahun 1998 - Nomor 23/SKB/M/XII/1998.

Tahun 2000 Pemerintah Pusat melalui Inpres No. 3 Tahun 2000 dan Keputusan Menteri Pertambangan dan Energi Nomor 1091K/70/MPE/2000 membentuk Koordinasi Penanggulangan Masalah Pertambangan Tanpa Izin. Pelaksanaan kegiatan ditekankan kepada penanggulangan secara fungsional oleh seluruh instansi yang ditentukan dalam Inpres di atas, dengan Tim Terpadu yang berfungsi sebagai forum koordinasi dalam upaya penyelesaian terhadap permasalahan yang bersifat lintas sektoral, di mana tindak 
lanjutnya tetap dilakukan secara fungsional dan sesuai kewenangannya oleh institusiinstitusi terkait.

Selanjutnya, menurut Otong Rosadi pada tahun 2009 pemerintah mengeluarkan UU No 4 Tahun 2009 tentang Pertambangan Mineral dan Batu Bara yang diundangkan tanggal 12 Januari 2009. Terdiri dari 175 pasal dan XXVI bab (Otong Rosadi, 2012:54). UU No. 4 Tahun 2009 tentang Pertambangan Mineral dan Batu Bara lahir setelah melalui perdebatan yang cukup panjang. UU No. 4 Tahun 2009 tentang Pertambangan Mineral dan Batu Bara mengatur tentang kegiatan usaha pertambangan dan salah satunya adalah mengenai perizinan usaha pertambangan seperti diatur dalam Pasal 37 dan Pasal 38.

Berdasarkan uraian di atas, maka permasalahan yang akan dibahas adalah bagaimanakah efektivitas penyidikan tindak pidana penambangan emas tanpa izin di Kabupaten Solok Selatan yang dilakukan oleh Ditreskrimsus Polda Sumbar? serta apa sajakah kendala-kendala yang dihadapi oleh Ditreskrimsus Polda Sumbar dalam penyidikan tindak pidana penambangan emas tanpa izin di Kabupaten Solok Selatan?

\section{METODE PENELITIAN}

Untuk menjawab permasalahan seperti yang telah diuraikan diatas, maka dalam melaksanakan penelitian yang berfungsi sebagai acuan, sehingga hasil dari penelitian dapat menemui sasaran dan dapat di pertanggung jawabkan.

Spesifikasi penelitian ini adalah deskriptif analitis. Pendekatan yang digunakan adalah pendekatan yuridis normatif sebagai pendekatan utama yang didukung oleh pendekatan yuridis empiris. Sumber data yang digunakan yaitu data primer dan data sekunder. Teknik pengumpulan data yang digunakan untuk data sekunder diperoleh dengan mempelajari berbagai literatur dan untuk data primer diperoleh langsung dari narasumber meliputi wawancara (interview) dan studi kepustakan. Data dianalisis dengan menggunakan teknik analisis deksriptif kualitatif.

\section{HASIL PENELITIAN DAN ANALISIS}

Efektivitas Penyidikan Tindak Pidana Penambangan Emas Tanpa Izin di Kabupaten Solok Selatan yang Dilakukan oleh Ditreskrimsus Polda Sumbar

Indonesia adalah negara yang memiliki sumber daya alam yang berlimpah. Kekayaan alam itu termasuk bahan galian (tambang) yang mencakup mineral dan batubara. Sumberdaya mineral sebagai salah satu kekayaan alam yang dimiliki bangsa Indonesia, yang apabila dikelola dengan baik akan memberikan kontribusi terhadap pembangunan ekonomi negara. Dalam hal ini, Pemerintah sebagai penguasa sumber daya tersebut, sesuai dengan amanat UUD Tahun 1945, harus mengatur tingkat penggunaannya 
untuk mencegah pemborosan potensi yang dikuasainya dan mengoptimal-kan pendapatan dari pengusahaan sumber daya tersebut sehingga dapat diperoleh manfaat yang sebesar-besarnya bagi kemakmuran rakyat. ${ }^{4}$

Sumber daya mineral dalam hal ini pertambangan memiliki sifat tersendiri yaitu lokasi penyebaran dan ukurannya terbatas, terdapat di dalam bumi mulai dari permukaan tanah sampai kedalaman tertentu, hanya dapat ditambang satu kali karena tak terbarukan (non-renewable resources), waktu pemanfaatannya terbatas (hanya beberapa tahun), resiko investasi sangat tinggi, padat modal dan teknologi, persiapan sebelumnya penambangan lama (lebih kurang 5 (tahun). ${ }^{5}$

Kegiatan penambangan di Indonesia kini banyak dipersoalkan oleh berbagai kalangan, termasuk di wilayah Kabupaten Solok Selatan yang memiliki potensi sumber daya alam berupa mineral logam emas cukup besar dengan kualitas yang baik. Daerah Solok Selatan cukup kaya dengan sumberdaya alam terutama barang tambang namun potensi tersebut belum termanfaatkan secara maksimal. Hal ini disebabkan oleh karena keterbatasan modal dan sumberdaya manusia yang ada. Sektor pertambangan belum digali secara optimal sehingga belum dapat memberikan manfaat yang besar bagi peningkatan keejahteraan masyarakat. Namun

4 Gatot Supramono, Hukum Pertambangan Mineral dan Batubara di Indonesia, Rineka Cipta, Jakarta, 2012, Cetakan 1., hlm. 1

${ }^{5}$ Ibid. demikian, potensi bahan-bahan galian berupa mineral logam, batu bara serta mineral bukan logam dan batuan yang cukup besar dan tersebar di berbagai tempat telah mulai dilakukan oleh pengusaha secara mekanis. Pengolahan bahan galian berupa mineral logam, batu bara serta mineral bukan logam dan batuan sebagaimana diatur PP Nomor 1 Tahun 2017 tentang Perubahan Keempat Atas PP Nomor 23 Tahun 2010 tentang Pelaksanaan Kegiatan Usaha Pertambangan Mineral dan Batu Bara sudah memberikan kontribusi pada APBD Kabupaten Solok Selatan. Meskipun demikian, perhatian pengolahan harus tetap memperhatikan kelestarian lingkungan.

Bahan tambang seperti, emas, timah hitam, biji besi, tembaga, mangan dan perak tersebar pada beberapa kecamatan di Kabupaten Solok Selatan. Sementara itu bahan galian industri yang masih dalam penyelidikan adalah bentonit, granit, marmer, obsidian, batu giok dan batu kapur. Pengelolaan tambang emas di Kabupaten Solok Selatan saat ini masih dilakukan secara tradisional, namun justru ini menjadi suatu masalah-masalah kecil di Kabupaten Solok Selatan yang dibiarkan dan lama-kelamaan dan suatu saat akan menjadi masalah yang besar, karena sebagian besar dilakukan tanpa izin atau ilegal.

Pertambangan Tanpa Izin (PETI) di Kabupaten Solok Selatan merupakan usaha pertambangan yang dilakukan oleh 
perseorangan maupun sekelompok orang yang dalam operasinya tidak memiliki izin dan instansi pemerintah sesuai peraturan perundang-undangan yang berlaku. PETI diawali oleh keberadaan para penambang tradisional, yang kemudian berkembang karena adanya faktor kemiskinan, keterbatasan lapangan kerja dan kesempatan usaha, keterlibatan pihak lain yang bertindak sebagai cukong dan backing, ketidak harmonisan hubungan antara perusahaan dengan masyarakat setempat, serta krisis ekonomi berkepanjangan. Selain itu, kelemahan dalam penegakan hukum dan peraturan perundang-undangan yang menganaktirikan pertambangan (oleh) rakyat, juga ikut mendorong maraknya PETI di Kabupaten Solok Selatan.

Ketentuan pidana pertambangan, kedudukanya sebagai tindak pidana di luar KUHP yang diatur menyimpang sesuai dengan ketentuan Pasal 103 KUHP. Karena tindak pidana pertambangan dapat menimbulkan bahaya di berbagai bidang yang berakibat merugikan masyarakat luas dan lingkungan hidup. Berdasarkan UU No. 4 Tahun 2009 tentang Pertambangan Mineral dan Batubara, terdapat bermacam-macam tindak pidana, yang sebagaian besar ditujukan kepada pelaku usaha pertambangan dan hanya 1 (satu) yang ditujukan untuk pejabat penerbit izin di bidang pertambangan.

Untuk pencapaian tujuan tersebut tentulah harus dilaksanakan oleh segenap komponen bangsa, termasuk bidang penegakan hukum pidana. Hukum dalam suatu masyakat bertujuan untuk menciptakan adanya suatu ketertiban dan keselarasan dalam berkehidupan. Hukum itu mempunyai sifat mengatur dan memaksa. Suatu peraturan hukum adalah untuk keperluan penghidupan masyarakat, mengutamakan kepentingan masyarakat, bukan untuk keperluan atau kepentingan perseorangan atau golongan, hukum juga menjaga hak-hak dan menentukan kewajiban-kewajiban anggota masyarakatnya agar terciptanya suatu masyarakat yang teratur, adil, dan makmur. Penegakan hukum tidak dapat dilepaskan dari peran aparat penegak hukum.

Menurut Andi Hamzah, istilah penegak hukum sering disalahartikan, seakan-akan hanya bergerak di bidang hukum pidana atau hanya di bidang represif. Istilah penegakan hukum di sini meliputi, baik yang represif maupun preventif. ${ }^{6}$

Sehubungan dengan hal tersebut di atas, hukum pidana secara ideal menjamin ketertiban dengan memuat ketentuan larangan terhadap perbuatan-perbuatan mana yang tidak boleh dilakukan yang dapat diancam dengan hukuman atas pelanggaran larangan tersebut, dan mengatur pertanggung jawaban terhadap hukum pidana/siapa yang dapat dihukum serta menentukan hukuman apa yang dapat dijatuhkan terhadap orang yang

6 Andi Hamzah, Hukum Acara Pidana Indonesia, Sinar Grafika, Jakarta, 2010. Hlm. 134. 
melakukan perbuatan yang bertentangan dengan undang-undang. ${ }^{7}$

Dalam sistem peradilan pidana Indonesia lembaga Kepolisian merupakan lembaga pertama yang berkewajiban melaksanakan penegakan hukum. Kepolisian Negara Republik Indonesia (Polri) sebagai alat negara dalam sistem pemerintahan Indonesia di bidang yudikatif, serta sistem peradilan pidana Indonesia lembaga Kepolisian merupakan lembaga pertama yang berkewajiban melaksanakan penegakan hukum, Polri sebagai salah satu institusi aparat penegak hukum yang mengemban fungsi pelayanan publik dituntut untuk mampu memberikan pelayanan yang terbaik kepada masyarakat dengan menampilkan kinerja kesatuan yang proposional dan profesional di bidangnya. Pasal 13 UU No. 2 Tahun 2002 tentang Kepolisian Negara Republik Indonesia, menyebutkan bahwa Polri memiliki beberapa tugas pokok yaitu memelihara keamanan dan ketertiban masyarakat, menegakkan hukum serta memberikan perlindungan, pengayoman dan pelayanan masyarakat.

Kitab Undang-Undang Hukum Acara Pidana (KUHAP), memberikan peran kepada Kepolisian Negara Republik Indonesia untuk melaksanakan tugas penyelidikan dan penyidikan tindak pidana secara umum tanpa batasan lingkungan kuasa sepanjang masih

${ }^{7}$ Bambang Waluyo, Pidana dan Pemidanaan, Sinar Grafika, Jakarta, 2008. Hlm. 6-7. termasuk dalam lingkup hukum publik, sehingga pada dasarnya Polri oleh KUHAP diberi kewenangan untuk melakukan penyelidikan dan penyidikan terhadap semua tindak pidana. UU No. 4 Tahun 2009 tentang Pertambangan Mineral dan Batubara dalam BAB XXI Penyidikan Pasal 149 ayat (1) mengatur tentang kewenangan penyidik tindak pidana pertambangan adalah pejabat Polri dan PPNS.

POLRI dalam hal ini Ditreskrimsus Polda Sumbar merupakan garda terdepan dalam hal pemberantasan PETI di Kabupaten Solok Selatan, bahkan Polda Sumbar sendiri telah menempatkan PETI di Kabupaten Solok Selatan sebagai kasus yang mendapat perhatian serius atau diutamakan, namun tugas berat tersebut tentunya tidak akan berhasil tanpa adanya dukungan dari semua elemen masyarakat.

Polda Sumbar merupakan instansi yang berperan dalam penegakan hukum dan norma yang hidup dalam masyarakat (police as an enforcement officer). Pada pelaksanaan demikian, Polda Sumbar adalah instansi yang dapat memaksakan berlakunya hukum. Ketika hukum dilanggar, terutama oleh perilaku yang menyimpang berupa tindak kejahatan, diperlukan peran polisi untuk memulihkan keadaan (resitutio in intregumen) pemaksa agar si pelanggar hukum menanggung akibat hukumnya.

Menurut Pasal 2 UU No. 2 Tahun 2002 bahwa fungsi kepolisian adalah salah satu 
fungsi pemerintahan negara di bidang pemeliharaan keamanan dan ketertiban masyarakat, penegak hukum, perlindungan, pengayoman dan pelayanan kepada masyarakat. Khusus dalam penanggulangan PETI, peran dan fungsi Polri tidak hanya dititikberatkan kepada penegakan hukum tetapi juga kepada pencegahan PETI di Kabupaten Solok Selatan.

KUHAP memberikan peran kepada Polri untuk melaksanakan tugas penyelidikan dan penyidikan tindak pidana secara umum tanpa batasan lingkungan kuasa sepanjang masih termasuk dalam lingkup hukum publik sehingga pada dasarnya Polri oleh KUHAP diberi kewenangan untuk melakukan penyelidikan dan penyidikan terhadap semua tindak pidana. UU No. 4 Tahun 2009 tentang Pertambangan Mineral dan Batubara dalam BAB XXI Penyidikan Pasal 149 ayat (1) mengatur tentang kewenangan penyidik tindak pidana pertambangan adalah pejabat Polri dan PPNS.

Proses penyidikan merupakan tahap yang paling dasar dalam Sistem Peradilan Pidana, di mana tugas penyidikan merupakan wewenang Polri, sehingga sangat kompleks dalam proses penyidikan itu sendiri, selain sebagai penyidik juga sebagai pengawas serta sebagai koordinator bagi penyidik PPNS. Kompleksitas tugas penyidik Polri semakin bertambah seiring dengan bergulirnya reformasi di segala bidang kehidupan di Indonesia. Penyidik dituntut untuk berhasil mengungkap semua perkara yang terindikasi telah melanggar hukum berdasarkan peraturan perundang-undangan yang berlaku.

Polda Sumbar dalam mengemban tugas pokok penegakan hukum terdiri dari beberapa fungsi antara lain: Direktorat Reserse Kriminal Khusus (Ditreskrimsus), Direktorat Reserse Kriminal Umum (Ditreskrimum), Direktorat Reserse Narkoba (Ditresnarkoba), Ditrektorat Lalu Lintas,dan Direktorat Kepolisian Air (Ditpolair). Direktorat Polda Sumbar yang memiliki tugas pokok penegakan hukum di bidang tindak pidana pertambangan mineral dan batubara adalah Direktorat Reserse Kriminal Khusus (Ditresksrimsus).

Ditreskrimsus memiliki fungsi teknis pembinaan reskrim khusus terhadap penyidik Polri di jajaran wilayah hukum Kota (Polresta) dan atau Kepolisian Resor (Polres) yang memiliki unit tindak pidana tertentu (tipidter) pada saat menangani perkaraperkara dalam proses penyidikan menggunakan undang-undang khusus di luar Kitab Undang-Undang Hukum Pidana (KUHP) dan KUHAP.

Berdasarkan uraian di atas, pihak Ditreskrimsus Polda Sumbar telah melakukan upaya penyidikan terhadap pelaku tindak pidana penambangan emas tanpa izin di Kabupaten Solok Selatan. Polda Sumbar khususnya Ditreskrimsus dalam mengemban tugas pokok penegakan hukum di bidang tindak pidana penambangan emas tanpa izin. 
Ditreskrimsus memiliki fungsi teknis pembinaan reskrim khusus terhadap penyidik Polri di jajaran wilayah hukum Kota (Polresta) dan atau Kepolisian Resor (Polres) yang memiliki unit tindak pidana tertentu (Tipidter) pada saat menangani perkaraperkara dalam proses penyidikan menggunakan undang-undang khusus di luar KUHP dan KUHAP. Khusus tentang penyidikan diatur dalam Pasal 106 sampai dengan Pasal 136 KUHAP.

Berdasarkan analisa penulis terhadap penyidikan tindak pidana penambangan emas tanpa izin di Kabupaten Selatan yang dilakukan oleh Ditreskrimsus Polda Sumbar adalah sebagai berikut:

1. Dari 3 (tiga) kasus yang terjadi yakni 1 (satu) kasus pada tahun 2015 dan 2 (dua) kasus pada tahun 2016 masing-masing kasus telah ditemukan alat bukti yang sah sebagai dasar untuk dapat dilakukan penahanan;

2. Pola penyidikan tindak pidana PETI di Kabupaten Solok selatan yang dilakukan oleh Ditreskrimsus Polda Sumbar diawali oleh adanya info tentang kegiatan penambangan emas tanpa izin yang bisa berasal dari orang lain, lembaga/LSM, media massa, surat anonim/kaleng, dan lain-lain kemudian ditindaklanjuti dengan pencarian barang bukti kemudian dilakukan penyelidikan. Dari 3 (tiga) kasus yang terjadi semuanya telah ditemukan bukti permulaan yang cukup, maka dilakukan penyidikan kemudian dilakukan lidik, tindak, pemeriksaan, pemberkasan kemudian penyerahan perkara ke JPU.

3. Lamanya penyidikan

Dari 3 (kasus) yang terjadi dalam melakukan penyidikan pihak penyidik tidak memerlukan waktu lama hanya berkisar lebih kurang 1 (satu) minggu). Dari 3 (tiga) kasus tersebut, 1 (satu) kasus ditahan oleh di Kepolisian Resor Solok Selatan dan 2 (dua) langsung dibawa ke Padang.

Setelah proses penyidikan yang dilakukan langkah selanjutnya yang dilakukan oleh Ditreskrimsus Polda Sumbar adalah sebagai berikut:

a. Penangkapan

Penangkapan adalah suatu tindakan penyidik berupa penangkapan sementara waktu kebebasan tersangka atau terdakwa apabila terdapat cukup bukti guna kepentingan penyidikan atau penuntutan dan atau peradilan dalam hal serta menurut cara yang diatur dalam undang-undang. ${ }^{8}$ Alasan penangkapan:

1) Seorang tersangka diduga keras melakukan tindak pidana;

2) Dan dugaan yang kuat itu, didasarkan pada permulaan bukti yang cukup (M. Yahya Harahap, 2007:158).

\footnotetext{
${ }^{8}$ Laden Marpaung, Proses Penanganan Perkara Pidana (Penyelidikan \& Penyidikan), Sinar Grafika, Jakarta, 2009. Hlm. 109.
} 
Penangkapan terhadap tersangka diatur dalam Pasal 16 sampai dengan Pasal

\section{KUHAP.}

b. Penahanan

Penahanan adalah penempatan tersangka atau terdakwa di tempat tertentu oleh penyidik atau penuntut umum atau hakim dengan penempatannya, dalam hal serta menurut cara yang diatur dalam undang-undang.

Perintah penahanan atau penahanan lanjutan dilakukan terhadap tersangka atau terdakwa yang diduga keras melakukan tindak pidana berdasarkan bukti yang cukup, dalam hal adanya keadaan yang menimbulkan kekhawatiran bahwa tersangka atau terdakwa akan melarikan diri, merusak atau menghilangkan barang bukti, dan atau mengulangi tindak pidana. Penahanan tersangka diatur dalam Pasal 20 sampai dengan Pasal 31 KUHAP.

c. Penggeledahan

Penggeledahan adalah tindakan penyidik yang dibenarkan undang-undang untuk memasuki dan melakukan pemeriksaan di rumah tempat kediaman seseorang atau untuk melakukan pemeriksaan terhadap badan dan pakaian seseorang. ${ }^{9} \quad$ Penggeledahan dilakukan untuk kepentingan penyelidikan dan atau penyidikan, agar dapat dikumpulkan fakta

9 M. Yahya Harahap, Pembahasan Permasalahan dan Penerapan KUHP Penyidikan dan Penuntutan, Sinar Grafika, Jakarta, 2007. Hlm. 248. dan bukti yang menyangkut suatu tindak pidana. Penggeledahaan diatur dalam Pasal 32 sampai dengan Pasal 37 KUHAP.

d. Penyitaan

Penyitaan adalah tindakan hukum yang dilakukan pada taraf penyidikan. Sesudah lewat taraf penyidikan tidak dapat lagi dilakukan penyitaan untuk dan atas nama penyidik. ${ }^{10}$ Penyitaan diatur di dalam Pasal 38 sampai dengan Pasal 48 KUHAP. Penyitaan hanya dapat dilakukan oleh penyidik dengan surat izin Ketua Pengadilan Negeri setempat.

Dalam hal tertangkap tangan penyidik dapat menyita benda dan alat yang ternyata atau yang patut diduga telah dipergunakan untuk melakukan tindak pidana atau benda lain yang dapat dipakai sebagai barang bukti. Di dalam tindak pidana penambangan emas ilegal banyak sekali barang bukti yang disita oleh penyidik seperti mesin sedot (dompeng), kapal kayu, emas, dan bahan bakar minyak serta alat-alat lain yang digunakan pelaku untuk melakukan kegiatan penambangan emas ilegal.

\section{Penyerahan Berkas Perkara}

Tujuan pemeriksaan penyidikan tindak pidana menyiapkan hasil pemeriksaan penyidikan sebagai "berkas perkara" yang akan diserahkan penyidik kepada penuntut umum sebagai instansi yang bertindak dan

\footnotetext{
${ }^{10}$ Ibid. Hlm. 249.
} 
berwenang melakukan penuntutan terhadap tindak pidana. Berkas hasil penyidikan itu yang dilimpahkan penuntut umum kepada hakim di muka persidangan pengadilan. Oleh karena itu, apabila penyidik berpendapat, pemeriksaan penyidikan telah selesai dan sempurna, secepatnya mengirimkan berkas perkara hasil penyidikan kepada penuntut umum.

Akan tetapi di dalam pengiriman berkas perkara, penyidik diharuskan menyesuaikan pemberkasan perkara dengan ketentuan Pasal Undang-Undang yang menggariskan pembuatan berita acara pemeriksaan penyidikan seperti yang ditentukan dalam Pasal 121 KUHAP. Seperti yang telah disinggung di atas, setelah penyidik berpendapat segala sesuatu pemeriksaan yang diperlukan dianggap cukup, penyidik "atas kekuatan sumpah jabatan" segera membuat berita acara dengan persyaratan-persyaratan yang ditentukan dalam Pasal 121:

1. Memberi tanggal pada berita acara;

2. Memuat tindak pidana yang disangkakan dengan menyebut waktu, tempat, dan keadaan sewaktu tindak pidana dilakukan;

3. Nama dan tempat tinggal tersangka dan saksi-saksi;

4. Keterangan mengenai tersangka dan saksi (umur, kebangsaan, agama, dan lain-lain);

5. Catatan mengenai akta dan atau benda;

6. Serta segala sesuatu yang dianggap perlu untuk kepentingan penyelesaian perkara.
Demikian syarat pembuatan berita acara yang ditentukan dalam Pasal 121. Akan tetapi, untuk lengkapnya berita acara harus dihubungkan dengan ketentuan Pasal 75.

Berdasarkan uraian di atas, dapat diketahui bahwa pelaksanaan penyidikan tindak pidana penambangan emas tanpa izin di Kabupaten Solok Selatan yang dilakukan oleh Ditreskrimsus Polda Sumbar telah efektif karena dari 3 (kasus) yang terjadi semuanya telah dilakukan penyidikan dan telah dilimpahkan ke Pengadilan karena telah memenuhi unsur-unsur tindak pidana yang diatur dalam peraturan perundang-undangan.

\section{Kendala yang Dihadapi oleh Ditreskrimsus Polda Sumbar dalam Penyidikan Tindak Pidana Penambangan Emas Tanpa Izin di Kabupaten Solok Selatan}

Penegakan hukum adalah suatu proses untuk mewujudkan keinginan-keinginan hukum menjadi kenyataan. Keinginankeinginan hukum adalah pikiran-pikiran badan pembuat undang-undang yang dirumuskan dalam peraturan-peraturan hukum. Sering didengar dalam rangka penegakan hukum, istilah diskresi. Diskresi diperlukan sebagai pelengkap asas legalitas, yaitu asas hukum yang menyatakan bahwa setiap tindakan atau perbuatan administrasi negara harus berdasarkan ketentuan undangundang. ${ }^{11}$

11 Nyoman Serikat Putra Jaya, Beberapa Kepemikiran Kearah Pengembangan Hukum Pidana, PT. Citra Aditya Bhakti, Bandung, 2008. Hlm. 135. 
Penegakan hukum merupakan harapan yang tidak realistis, terdapat kendala-kendala dalam pelaksanaannya berupa batasan waktu, personel, alat-alat investigasi, dana dan sebagainya. Dalam hal penambangan emas ilegal di Kabupaten Solok Selatan merupakan permasalahan antara kelangsungan hidup hari ini dan masa depan lingkungan untuk generasi di masa yang akan datang.

Penambangan emas ilegal ini bukan saja merusak lingkungan di Kabupaten Solok Selatan tetapi kegiatan penambangan emas ilegal ini juga telah merusak moral masyarakat terutama generasi muda Solok Selatan. Jadi, sudah seharusnya kegiatan penambangan emas ilegal ini diberantas demi kemakmuran seluruh masyarakat Solok Selatan. Namun, pemberantasan tambang emas ilegal ini tidak semudah membalikkan telapak tangan. Ditreskrimsus Polda Sumbar sebagai lembaga penegak hukum yang mempunyai wewenang untuk bertindak memberantas kegiatan tambang emas ilegal yang terjadi di Kabupaten Solok Selatan menghadapi banyak kendala dalam melaksanakan penegakan hukum terhadap para pelaku penambangan emas ilegal tersebut. Adapun kendala-kendala yang dihadapi oleh pihak Direktorat Reserse Kriminal Khusus Kepolisian Daerah Sumatera Barat dalam penyidikan tindak pidana penambangan emas tanpa izin di Kabupaten Solok Selatan, antara lain:
1. Belum bersinerginya dalam mendukung penegakan hukum secara bersama antar instansi terkait lainnya

Belum bersinerginya dalam mendukung penegakan hukum secara bersama antar instansi terkait lainnya karena pelaku penambangan emas ilegal di back-up oleh oknum-oknum yang tidak bertanggung jawab. Berdasarkan pengamatan langsung penulis di lapangan, penulis melihat para pelaku penambangan emas ilegal ini di back-up oleh oknumoknum yang tidak bertanggung jawab seperti oknum penegak hukum, oknum pemerintah, hingga oknum pemangku adat. Para pelaku penambangan sering mendapatkan bocoran informasi razia dari oknum polisi itu sendiri. Jika para pelaku sudah mendapatkan bocoran informasi akan dilakukannya razia oleh polisi, maka para pelaku akan secepat mungkin untuk menyembunyikan alat-alat tambang yang mereka gunakan.

Berdasarkan pengakuan salah seorang pelaku penambangan emas ilegal bahwa dia bersama pelaku lainnya mendapatkan informasi tentang razia yang akan dilakukan, yaitu dari oknum polisi yang bertugs di Polsek setempat. Mereka setiap minggunya harus menyetor uang kepada oknum tersebut, yang sering mereka sebut sebagai uang keamanan. Penulis melihat tindakan yang dilakukan oleh oknum kepolisian merupakan 
tindakan yang tidak dibenarkan oleh peraturan perundang-undangan yang ada. Seharusnya, kepolisian yang menjadi lini terdepan dalam penegakan hukum dapat memberikan pengetahuan serta pemahaman tentang hukum agar terwujud masyarakat yang sadar dan taat akan hukum.

Demikian pula dengan adanya kesadaran hukum baik aparatur penegak hukum maupun masyarakat, maka akan tercipta pula kesdaran akan lingkungan mengingat emas merupakan sumber daya alam yang tidak dapat diperbaharui dan harus dikelola dengan baik demi mencapai tujuan yang diharapkan, yaitu Sustainable Development (pembangunan berkelanjutan).

2. Terbatasnya sarana dan prasarana

Dalam kegiatan tambang emas ilegal ini yang menjadi pelaku tindak pidana penambangan emas ilegal bukan saja para pekerja tambang, tetapi pemilik alat tambang juga disebut sebagai pelaku. Biasanya para pemilik alat tambang akan melarikan diri setelah dia mendapatkan informasi bahwa anak buahnya atau pekerja tambangnya tertangkap saat polisi melakukan razia.

Berdasarkan hasil penelitian yang dilakukan diketahui bahwa terbatasnya sarana dan prasarana yang dimiliki oleh Ditreskrimsus Polda Sumbar di antaranya: a. Keterbatasan alat transportasi yang dimiliki untuk menjangkau lokasi baik di darat maupun di perairan atau sungai;

b. Dalam pelaksanaan penyelidikan dan penyidikan untuk menuju lokasi memerlukan jumlah personel, sarana dan prasarana, waktu pelaksanaan dan jumlah biaya yang sangat besar mengingat TKP tersebar tidak satu tempat.

Penulis berpendapat sulitnya dilakukan penangkapan terhadap pelaku penambangan emas ilegal disebabkan minimnya sarana atau fasilitas yang digunakan oleh aparat penegak hukum. Dalam menjalankan tugasnya memberantas kegiatan penamban-gan emas ilegal yang paling dibutuhkan terutama adalah sarana fisik yang berfungsi sebagai faktor pendukung.

Bagaimana penegak hukum dapat bekerja dengan baik apabila tidak dilengkapi dengan kendaraan dan alat-alat komunikasi yang proporsional. Tanpa adanya sarana atau fasilitas tertentu, maka tidak mungkin penegakan hukum akan berlangsung dengan lancar. Sarana atau fasilitas tersebut, antara lain mencakup juga tenaga manusia yang berpendidikan dan terampil, organisasi yang baik, peralatan yang memadai, keuangan yang cukup dan seterusnya. Sementara berdasarkan fakta yang penulis temukan di lapangan, pelaku penambangan emas ilegal atau sebagai pemilik alat tambang dapat melarikan diri 
disebabkan pelaku ini memiliki cara-cara yang cerdik dalam menjalankan kegiatan penambangan emas ilegal, oleh sebab itu dalam pemberantasan nya harus pula didukung oleh fasilitas yang memadai seperti tenaga manusia penegak hukum yang berpendidikan dan terampil, organisasi yang baik dari penegak hukum, peralatan yang memadai, dan keuangan yang cukup karena hal ini berkaitan terhadap pengejaran pelaku.

\section{PENUTUP}

Efektivitas penyidikan tindak pidana penambangan emas tanpa izin di Kabupaten Solok Selatan yang dilakukan oleh Ditreskrimsus Polda Sumbar berdasarkan data yang diperoleh adalah telah efektif karena dari 3 (kasus) yang terjadi semuanya telah dilakukan penyidikan dan telah dilimpahkan ke Pengadilan karena telah memenuhi unsurunsur tindak pidana yang diatur dalam peraturan perundang-undangan.

$$
\text { Kendala yang dihadapi oleh }
$$

Ditreskrimsus Polda Sumbar dalam penyidikan tindak pidana penambangan emas tanpa izin di Kabupaten Solok Selatan meliputi: (a) Belum bersinerginya dalam mendukung penegakan hukum secara bersama antar instansi terkait lainnya karena pelaku penambangan emas ilegal ini di back-up oleh oknum-oknum yang tidak bertanggung jawab seperti oknum penegak hukum, oknum pemerintah, hingga oknum pemangku adat; serta (b) Terbatasnya sarana dan prasarana seperti tidak memiliki mobil double gardan atau perahu yang dapat menjangkau medan berat serta tidak memiliki alat komunikasi satelit yang dapat dioperasionalkan di lokasi yang tidak terjangkau oleh jaringan telepon seluler.

\section{DAFTAR PUSTAKA}

\section{Buku-buku}

Andi Hamzah, Hukum Acara Pidana Indonesia, Sinar Grafika, Jakarta, 2010.

Bambang Waluyo, Pidana dan Pemidanaan, Sinar Grafika, Jakarta, 2008.

Danny Z. Herman, Pertambangan Tanpa Izin (PETI) dan Kemungkinan Alih Status Menjadi Pertambangan Skala Kecil, Kelompok Kerja Konservasi - Pusat Sumber Daya Geologi, Jakarta, 2009.

Gatot Supramono, Hukum Pertambangan Mineral dan Batubara di Indonesia, Rineka Cipta, Jakarta, 2012, Cetakan 1.

Kompas, Pemberdayaan Pertambangan Skala Kecil Belum Optimal, Edisi 09 Desember 2011.

Laden Marpaung, Proses Penanganan Perkara Pidana (Penyelidikan \& Penyidikan), Sinar Grafika, Jakarta, 2009.

M. Yahya Harahap, Pembahasan Permasalahan dan Penerapan KUHP Penyidikan dan Penuntutan, Sinar Grafika, Jakarta, 2007.

Nyoman Serikat Putra Jaya, Beberapa Kepemikiran Kearah Pengembangan Hukum Pidana, PT. Citra Aditya Bhakti, Bandung, 2008.

Otong Rosadi, Pertambangan dan Kehutanan dalam Perspektif Cita Hukum Pancasila, Dialektika Hukum dan Keadilan Sosial, Thafa Media, Yogyakarta, 2012. 


\section{Perundang-undangan}

Undang-Undang Dasar Negara Republik Indonesia Tahun 1945.

Undang-Undang Nomor 1 Tahun 1946 tentang Peraturan Hukum Pidana (KUHP).

Undang-Undang Nomor 11 Tahun 1967 tentang Ketentuan-Ketentuan Pokok Pertambangan.

Undang-Undang Nomor 8 Tahun 1981 tentang Kitab Undang-Undang Hukum Acara Pidana (KUHAP).

Undang-Undang Nomor 4 Tahun 2009 tentang Pertambangan Mineral dan Batu Bara.

Undang-Undang Nomor 23 Tahun 2014 tentang Pemerintahan Daerah.

Peraturan Pemerintah Republik Indonesia Nomor 23 Tahun 2010 tentang Pelaksanaan Kegiatan Usaha Pertambangan Mineral dan Batu Bara.

Peraturan Pemerintah Republik Indonesia Nomor 58 Tahun 2010 tentang Perubahan Atas Peraturan Pemerintah Republik Indonesia Nomor 27 Tahun 1983 tentang Pelaksanaan Kitab Undang-Undang Hukum Acara Pidana.

Peraturan Pemerintah Republik Indonesia Nomor 1 Tahun 2017 tentang Perubahan Keempat Atas Peraturan Pemerintah Nomor 23 Tahun 2010 tentang Pelaksanaan Kegiatan Usaha Pertambangan Mineral dan Batu Bara.

Instruksi Presiden Nomor 3 Tahun 2000 dan Keputusan Menteri Pertambangan dan Energi Nomor 1091K/70/MPE/2000 tentang Koordinasi Penanggulangan Masalah Pertambangan Tanpa Izin.

Keputusan Bersama Menteri Pertambangan dan Energi, Menteri Dalam Negeri dan Menteri Pengusaha Kecil dan Menengah; Nomor 2002.K/20/MPE/1998 - Nomor 151A Tahun 1998 - Nomor 23/SKB/M/XII/1998.
Peraturan Daerah Provinsi Sumatera Barat Nomor 3 Tahun 2012 tentang Pengelolaan Usaha Pertambangan Mineral dan Batubara.

\section{Artikel \& Website}

http://id.shvoong.com/ -pengertian-tindak pidana/\#ixzz1L4Z8MT7b

http://www.solselkab.go.id/.

www.KamusBahasaIndonesia.org. 